\title{
Kontrol Diri dengan Tingkat Agresivitas Remaja yang Memiliki Orangtua TNI atau POLRI
}

\author{
Ansih Mahliyatul Khoir ${ }^{1}$ \\ Fakultas Psikologi, Universitas Muhammadiyah Malang \\ e-mail: ${ }^{1}$ ansihmahliya30@gmail.com
}

\begin{abstract}
Aggressive behavior in adolescents can be minimized and reduced by using self-control. Self-control is needed for every individual, especially adolescents. Age and family's environment are the factors that underlie a person can control himself. The aims of this research are to knowing the relationship between self-control and the level of aggressiveness in adolescents who have TNI or POLRI parents. This research using quantitative correlational approarch with the data collections using quota sampling technique, the subjects of this research were aged 13 until 17 years old who have TNI or POLRI parents. The instrument of this research using self control scale from Tangney, Baumeister, and Boone theory, and also using aggressive scale from Baron. The results of this study showed that there was a significant negative relationship between self-control and the level of aggressiveness in adolescents who have TNI or POLRI parents. It means, the increasing of self-control possessed by adolescents, the level of aggressiveness will be decreases, in another hand the decreasing of self-control that teenager has, the level of aggressiveness will be increases.
\end{abstract}

KEYWORDS Self-control, aggressive behavior

CITATION Khoir, A. M. (2019). Kontrol diri dengan tingkat agresivitas remaja yang memiliki orang tua tni atau polri. Cognicia, 7, (2), 202-213.

Remaja adalah masa transisi dari anak-anak menuju dewasa, pada masa ini remaja akan mengalami proses dimana remaja tersebut mencari identitas diri dan mulai mengenali bagaimana dirinya. Dalam proses pencarian identitas diri tersebut remaja melakukannya dengan berbagai cara yang beresiko dapat menimbulkan masalah pada diri remaja tersebut dan akan berdampak juga pada lingkungannya. Pada masa ini, remaja juga rentan terhadap konflik karena biasanya terjadi berbagai perubahan-perubahan fisik maupun psikisnya. Pada perubahan fisik remaja ditandai dengan bertambahnya tinggi, berat badan, terjadi pertumbuhan tulang dan otot, serta terjadi kematangan organ seksual dan fungsi reproduksi. Sedangkan pada perubahan psikisnya, remaja menemukan bahwa dirinya merasa mampu memenuhi tanggung jawab seperti orang dewasa. Ketika fungsi dari fisik maupun psikisnya belum mencapai kematangan layaknya orang dewasa, maka akan terjadi tuntutan sosial yang dihadapi oleh remaja yang akan menyebabkan kegagalan dan menimbulkan perasaan frustasi, serta konflik tersendiri pada diri remaja (Hurlock, 2004).

Pada masa remaja, meskipun meningkatnya kematangan emosi, jati diri, dan rasa tanggung jawab yang dimilikinya, pengaruh-pengaruh dari luar masih sangat kuat mempengaruhi pikiran dan perilaku-periaku yang dilakukan remaja tersebut. 
Pada usia remaja perilaku seorang anak tentunya sudah semakin luas dibandingkan ketika masih berada di masa sebelumnya. Pada usia ini rata-rata remaja belum bisa memilah serta memilih secara tegas stimulus atau dorongan yang masuk pada dirinya, baik itu positif atau negatif. Ekspresi emosional yang masih labil dan belum terkendali pada masa remaja dapat berdampak pada kehidupan pribadi ataupun sosial remaja tersebut. Seharusnya seorang remaja sudah mampu memahami bagaimana menyikapi suatu bentuk perilaku, dimana remaja tersebut harus memiliki sikap yang sopan ketika berhadapan dengan orang yang lebih tua, bisa saling menghargai antar teman sebayanya, dan juga mampu mentaati peraturan atau norma yang sudah ditetapkan di lingkungan sekolah maupun masyarakat, tentunya perilaku-perilaku tersebut sudah ditanamkan oleh orangtua kepada anaknya terlebih dahulu sebagai bentuk pendidikan awal atau pondasi awal untuk anaknya agar dapat bersosialisasi di lingkungan sosialnya.

Berdasarkan hasil observasi yang dilakukan oleh peneliti pada tanggal 4 desember 2018 - 11 desember 2018 kepada siswa menengah pertama di salah satu SMP Negeri Kabupaten Trenggalek, terdapat beberapa fenomena perilaku remaja, seperti perilaku memberontak, baik dengan orangtua maupun dengan guru di sekolah, pelanggaran aturan norma baik di lingkungan masyarakat maupun di sekolah, ditambah lagi dengan banyaknya kasus adu fisik yang ada di sekolah dengan teman sebayanya. Perilaku-perilaku tersebut menunjukkan ciri-ciri dari perilaku agresif.

Fenomena tersebut terjadi karena kurangnya rasa hormat dan sopan terhadap guru maupun orangtua dirumah, yaitu dengan melanggar peraturan yang sudah diberikan, terjadi saling adu fisik. Dalam hal ini remaja masih belum mampu mengendalikan fungsi fisik maupun fungsi psikisnya (Monks, Knoers, Haditono, 2006). Hal tersebut berdampak pada pertumbuhan remaja, yaitu emosi yang belum mampu dikendalikan dan juga mendapat tekanan psikis yang membuat remaja sulit untuk mengontrol dirinya sendiri dan untuk mematuhi nilai-nilai dan norma yang ada dalam masyarakat. Konflik yang berkepanjangan yang dapat menyebabkan remaja memunculkan perasaan frustasi apabila remaja tersebut belum mampu menyelesaikan berbagai tekanan yang dialaminya. Kemudian dari reaksi dan ekspresi yang muncul dari perasaan frustasi yang dialaminya, membuat seorang remaja berperilaku yang tidak sesuai dengan aturan dan norma yang berlaku di dalam masyarakat, dari hal tersebut memunculkan kejadian-kejadian yang tidak diinginkan seperti terjadinya perkelahian, saling menggunakan kekerasan, melakukan kekejaman, serta berperilaku agresif yang lainnya (Koeswara, 1988).

Agresi itu sendiri pada dasarnya seperti merupakan tingkah laku individu yang ditujukan untuk melukai atau mencelakakan individu lain yang tidak menginginkan datangnya tingkah laku tersebut (Baron, 1994). Definisi dari Baron ini mencakup empat faktor tingkah laku, yaitu; tujuan untuk melukai atau mencelakakan, individu yang menjadi pelaku, individu yang menjadi korban dan ketidakinginan si korban menerima tingkah laku si pelaku. Munculnya perilaku agresif pada remaja ini diekspresikan melalui munculnya perasaan dendam terhadap orang lain dan meluapkan perasaan marah atau emosi kepada orang lain atau objek lain. Agresi secara verbal juga merupakan fenomena yang memprihatinkan mengingat manusia 
sebagai makhluk sosial memiliki kebutuhan dasar untuk berinteraksi dengan orang lain, terutama untuk bersosialisasi di lingkunganya masing-masing (Schneider, 2005).

Banyak hal yang melatar belakangi munculnya perilaku agresif pada remaja saat ini. Salah satunya yaitu remaja yang memiliki orangtua dengan latar belakang militer. Orangtua tersebut memiliki cara yang berbeda-beda dalam memberikan pengasuhan terhadap anaknya. Terdapat beberapa sudut pandang yang mengatakan bahwa pola pengasuhan yang diterapkan dalam keluarga militer adalah pola asuh otoriter, namun pada kenyataannya tidak semua orangtua yang berlatar belakang dari keluarga militer menggunakan pola asuh tersebut. Dalam hal ini terdapat kombinasi antara pengasuhan ayah dan ibu, karena ayah yang bekerja seharian dan menyerahkan pengasuhan kepada istrinya, maka anak dalam melakukan kegiatan sehari-harinya lebih banyak dihabiskan dengan ibunya (Emilianur \& Amri, 2017).

Pemilihan pola asuh yang tepat terhadap remaja sangat diperlukan karena akan berdampak pada psikologis remaja tersebut, seperti yang dikatakan oleh psikolog Elly Risman bahwa jika seorang remaja tidak mendapatkan kasih sayang dan pola pengasuhan yang tepat sejak mereka kecil maka akan berdampak pada perilaku anak ketika dewasa, seorang remaja yang tinggal di dalam keluarga yang dibiasakan untuk berperilaku disiplin dan dididik dengan sistem yang otoriter biasanya akan mengekspresikan dirinya di luar rumah. Banyak kasus yang menunjukkan bahwa anak dalam keluarga militer menerima banyak bentakan, sindiran, dan perbandingan dari orangtua saat kecil, akibatnya anak mencari cara untuk menetralkan perasaan buruk yang timbul dengan berbagai hal yang berdampak negatif pada dirinya, dan juga anak memiliki kemungkinan untuk berperilaku memberontak (Widiyani, 2014). Namun juga tidak bisa dipungkiri bahwa remaja yang kurang diperhatikan oleh orangtuanya juga akan mencari perhatian dengan menunjukkan perilaku yang salah, seperti adu fisik dengan teman sebayanya atau melanggar aturan-aturan yang ada.

Seorang remaja juga memiliki cara untuk bersosialisasi dengan lingkungannya. Pada proses interaksi tersebut remaja masih belum mampu menentukan mana perilaku yang sesuai dan tidak sesuai dengan nilai norma yang ada di masyarakat, sehingga perilaku remaja tersebut dapat meresahkan masyarakat. Menurut Becker (Soekanto, 1988) pada situasi tertentu setiap manusia akan memiliki dorongan untuk melanggar aturan, tetapi kebanyakan orang yang memiliki dorongan-dorongan tersebut biasanya tidak menjadi kenyataan yang berupa penyimpangan. Hal ini disebabkan biasanya seseorang dapat menahan diri dari dorongan-dorongan untuk berperilaku menyimpang.

Pada masa perkembangan beberapa remaja gagal dalam mengembangkan kontrol diri yang sudah dimiliki oleh remaja lain seusianya. Tugas seorang remaja adalah memiliki tanggung jawab serta mampu memahami nilai-nilai yang telah ada di masyarakat. Seorang remaja juga harus mampu mengendalikan dorongan-dorongan yang menjadi kebutuhan pemuasan untuk dirinya agar remaja tersebut tidak melanggar norma dan aturan yang sudah berlaku, hal tersebut menjadikan remaja sadar dan peka terhadap norma yang ada dalam masyarakat (Havighurst, Neugarten, \& Tobin, 1964).

Krahe (2001) juga mengatakan bahwa perilaku agresif yang muncul pada diri individu juga dapat dipengaruhi oleh dua faktor, yaitu faktor kepribadian dan faktor 
situasional. Faktor kepribadian yaitu kontrol diri, iritabilitas, kerentanan emosional, pikiran yang kacau, harga diri dan gaya atribusi permusuhan, sedangkan faktor situasional yaitu adanya penyerangan, efek senjata, karakteristik target, alkohol dan temperatur udara.

Perilaku agresif pada remaja tersebut sebenarnya dapat diminimalisir bahkan dikurangi, salah satunya melalui kontrol diri. Kontrol diri ini sangat diperlukan bagi setiap individu, khususnya remaja. Terdapat dua faktor yang mempengaruhi kontrol diri seseorang, yaitu faktor internal dan faktor eksternal. Faktor internal meliputi faktor usia dan kematangan, dimana semakin bertambah usia seseorang, maka kontrol diri yang dimiliki seseorang tersebut akan semakin baik, seseorang yang telah matang secara psikologis juga akan berdampak pada diri seseorang tersebut untuk dapat mengontrol perilakunya, karena pada dasarnya seseorang telah mampu mempertimbangkan mana hal yang baik dan hal yang buruk bagi dirinya. Sedangkan faktor eksternalnya adalah pengaruh lingkungan keluarga, karena lingkungan keluarga pastinya akan menjadi contoh dan teladan bagi sesorang anak, jika di dalam keluarga tersebut tidak mampu mengontrol emosinya maka anak juga akan semakin memperburuk keadaan (Hurlock, 1980). Dukungan keluarga juga bukan hanya sebagai penentu kualitas kontrol diri pada remaja, namun keluarga terutama orangtua mampu menentukan dan membatasi perilaku remaja seperti menghindarkan remaja dari perilaku yang menyimpang.

Kontrol diri sebagai kemampuan untuk membimbing tingkah laku sendiri, kemampuan untuk menekan, merintangi impuls-impuls atau tingkah laku impulsif (Chaplin, 2001). Dimana kontrol diri ini penting untuk dikembangkan karena individu tidak hidup sendiri melainkan bagian dari kelompok masyarakat. Individu mampu mengontrol diri berarti individu tersebut memiliki self control. Sedangkan menurut (Ghufron, 2010) setiap individu memiliki suatu mekanisme yang dapat membantu mengatur dan mengarahkan perilaku yaitu kontrol diri. Sebagai salah satu sifat kepribadian kontrol diri pada satu individu dengan individu lain tidaklah sama.

Baumeister, Vohs, dan Tice (2007) mengatakan bahwa kontrol diri merupakan proses yang berkembang pada individu melalui intervensi psikologis yang juga terjadi pada masa dewasa. Kontrol diri merupakan kemampuan yang dimiliki seseorang dalam mengubah respon secara sadar dan sengaja untuk membuat individu tersebut dapat menahan atau menghilangkan respon negatif dan mengubah respon tersebut menjadi respon lain yang lebih sesuai. Ketika respon negatif tersebut muncul, individu yang memiliki kontrol diri yang baik dapat mengendalikan dirinya untuk tidak berperilaku agresif.

Pada umumnya setiap individu memiliki kemampuan dan keinginan yang berbeda-beda dalam upaya mengendalikan kontrol diri, dan dari perbedaanperbedaan individual tersebut dapat berimplikasi pada aspek emosional, sosial, dan penyesuaian perilaku. Kontrol diri dan agresivitas ini dapat diibaratkan seperti dua kutub yang saling bertolak belakang, hal ini ditunjukkan dalam sebuah riset yang melihat seberapa kuatnya pengaruh sifat agresif dalam memprediksi munculnya perilaku marah, sementara di sisi lain kuatnya kontrol diri mengarah pada minimnya perilaku marah yang muncul (Brookings, DeRoo, \& Grimone, 2008). 
Ketika perilaku agresif pada diri individu tersebut menguat, maka kontrol diri dapat membantu seseorang untuk mengabaikan dorongan sifat agresivitasnya, dan juga dapat menolong individu tersebut untuk merespon sesuai dengan standar dirinya sendiri atau sosial. Melihat hal tersebut, dapat dipahami apabila kontrol diri rendah maka agresifnya akan meningkat, dan sebaliknya jika terdapat faktor-faktor yang menguatkan kontrol diri, maka di situlah kemudian agresif akan menurun (DeWall et al, 2011).

Dari permasalahan-permasalahan yang dialami oleh remaja tersebut, seperti halnya banyak remaja yang didapati sedang melakukan pelanggaran-pelanggaran aturan seperti remaja yang berperilaku memberontak dengan kedua orangtuanya atau dengan gurunya di sekolah, pelanggaran aturan norma baik di lingkungan masyarakat maupun di lingkungan sekolah, ditambah lagi dengan banyaknya kasus adu fisik antar teman sebayanya. Papalia, Olds dan Feldman (2009) mengatakan bahwa dalam suatu pertemanan adalah permasalahan yang utama bagi seorang remaja dalam hal bersikap dan gaya hidup remaja tersebut, apabila dalam kelompok teman sebayanya tersebut menerapkan sikap yang positif maka ada kemungkinan bahwa remaja juga akan menunjukkan pribadi yang baik, sebaliknya juga apabila dalam suatu kelompok teman sebayanya menerapkan sikap yang negatif maka akan terjadi juga kemungkinan remaja tersebut akan menampilkan pribadi yang kurang baik atau mungkin akan berperilaku agresif.

Bentuk-bentuk agresivitas pada remaja sangat beragam dan sering kita dengar baik itu melalui surat kabar, televisi, media sosial dan sebagainya. Hal ini dapat meresahkan masyarakat baik itu secara material maupun psikologis. Hal tersebut dapat kita lihat di masyarakat sekarang apabila ada perkelahian atau tawuran yang dilakukan oleh para remaja, mereka langsung melarikan diri untuk menyelamatkan diri tanpa menghiraukan lingkungannya. Menjadi seorang remaja yang pastinya akan mengalami banyak perubahan-perubahan dalam dirinya yang membuat seorang remaja tersebut memiliki kesulitan untuk mengendalikan diri dan mengontrol diri untuk berperilaku yang sesuai dengan nilai dan norma yang diterapkan di masyarakat. Maka dalam diri seorang remaja tersebut dibutuhkan kontrol diri agar dapat meminimalisir atau mengurangi dampak dari sikap dan perilaku baik dari diri remaja tersebut, dan juga dari lingkungan masyarakatnya. Berdasarkan fenomena-fenomena di atas maka peneliti ingin meneliti lebih lanjut mengenai "Kontrol diri dengan tingkat ggresifitas remaja yang memiliki orangtua TNI atau POLRI".

Berdasarkan penelitian terdahulu oleh (Ubaidillah, 2017) yang meneliti tentang hubungan antara kontrol diri dengan tingkat agresivitas pada remaja santri, menunjukkan bahwa tingkat kontrol diri 14,06\% pada kategori tinggi, 67,19\% pada kategori sedang, dan 18,75\% pada kategori rendah. Sedangkan pada tingkat agresivitas $14,06 \%$ pada kategori tinggi, 71,88\% pada kategori sedang, dan 14,06\% pada kategori rendah. Hasil uji korelasi menunjukkan adanya hubungan negatif yang signifikan antara kontrol diri dengan agresivitas pada subjek yang ditunjukkan dengan nilai $r_{x y}=-$ 0,477 dan nilai signifikansi $0,000<0,05$. Artinya semakin tinggi kontrol diri subjek maka subjek cenderung memiliki agresivitas yang rendah begitu juga sebaliknya, semakin rendah kontrol diri maka semakin tinggi agresivitasnya. 
Berdasarkan uraian di atas, maka rumusan masalah dalam penelitian ini adalah apakah terdapat hubungan antara kontrol diri dengan tingkat agresivitas pada remaja yang memiliki orangtua TNI atau POLRI. Tujuan dalam penelitian ini, yaitu untuk mengetahui hubungan kontrol diri dengan tingkat agresivitas pada remaja yang memiliki orangtua TNI atau POLRI. Sedangkan manfaat yang dapat diperoleh dari penelitian ini sebagai kajian dan informasi yang bisa diketahui oleh pembaca mengenai hubungan antara kontrol diri dan tingkat agresivitas pada remaja yang memiliki orangtua TNI atau POLRI, dan juga untuk mengetahui seberapa besar tingkat kontrol diri dengan tingkat agresivitas pada remaja yang memiliki orangtua TNI atau POLRI, agar remaja tersebut dapat berperilaku yang positif dan bisa menjadi pribadi yang lebih baik lagi dari sebelumnya.

Hipotesa peneliti yaitu terdapat hubungan negatif yang signifikan antara kontrol diri dengan tingkat agresivitas pada remaja yang memiliki orangtua TNI atau POLRI. Inidividu yang memiliki kontrol diri yang tinggi maka tingkat agresivitasnya rendah, sedangkan individu yang memiliki kontrol diri yang rendah maka individu tersebut tingkat agresivitasnya tinggi.

\section{METODE}

Metode penelitian ini menggunakan pendekatan korelasional kuantitatif yaitu sebuah penelitian yang menggunakan angka, mulai dari pengumpulan data, penafsiran terhadap data, serta hasil yang bertujuan untuk menemukan ada tidaknya hubungan dalam dua variabel. Alasan peneliti menggunakan pendekatan korelasional kuantitatif ini karena ingin mengetahui ada tidaknya hubungan antara kontrol diri dengan tingkat agresivitas pada remaja yang memiliki orangtua TNI atau POLRI.

Subjek dalam penelitian ini adalah remaja usia 12 sampai 17 tahun dan yang memiliki orangtua yang bekerja sebagai TNI atau POLRI. Teknik pengambilan data yang digunakan dalam penelitian ini adalah teknik quota sampling, yaitu teknik pengambilan sampel yang dilakukan dengan mengambil sejumlah kuota sampel dari populasi dan menghentikan pengambilan setelah kuota terpenuhi (Purwanto, 2015).

Variabel bebas dalam penelitian ini adalah kontrol diri. Kontrol diri adalah kemampuan yang dimiliki sesorang untuk mengatur hal-hal yang berhubungan dengan dirinya, berupa emosi maupun perilaku. Kontrol diri dapat mengendalikan perilaku negatif seseorang dengan cara mempertimbangkan terlebih dahulu. Kontrol diri ini akan diukur dengan menggunakan skala dari Tangney, Baumeister, dan Boone yang mencakup aspek self-dicipline, deliberate/nonimpulsive, healthy habits, work ethic, dan reliability. Variabel terikat dalam penelitian ini yaitu agresivitas. Agresivitas merupakan suatu perilaku yang bisa membahayakan orang lain dan yang ada di sekitarnya, dimana pelaku tersebut melakukan perilaku agresif dengan unsur yang disengaja untuk menyakiti lawanya. Agresivitas ini akan diukur menggunakan model skala likert yang diadaptasi dari Baron dengan mengukur tingkat agresivitas remaja berdasarkan aspek-aspek dari agresivitas, yaitu penyerangan dalam fisik, penyerangan suatu objek, penyerangan secara verbal, pelanggaaran terhadap hak milik. 
Tabel 1. Uji Validitas Instrumen Penelitian

\begin{tabular}{lcc}
\hline \multicolumn{1}{c}{ Instrumen } & Indeks validitas & Indeks Reliabilitas \\
\hline Skala agresivitas & $0.509-0.678$ & 0.800 \\
Skala kontrol diri & $0.507-0.839$ & 0.849 \\
\hline
\end{tabular}

Tingkat validitas dari data di atas menunjukkan skala agresivitas berkisar antara 0.509 - 0.678 dengan nilai uji reliabilitasnya 0.800 dan menunjukkan 22 item valid. Sedangkan skala kontrol diri tingkat validitasnya berkisar antara 0.507 - 0.839 dengan nilai uji reliabilitasnya 0.849 dan menunjukkan 23 item valid.

Dalam proses penelitian ini, terdapat tiga tahapan penelitian. Pertama, yaitu tahap persiapan, tahap, pelaksanaan, dan yang terakhir tahap analisis data. Dalam tahap pertama ini yaitu tahap persiapan, peneliti mengidentifikasi fenomenafenomena yang terdapat dalam masyarakat, dalam tahap ini peneliti juga mendalami teori-teori yang sesuai dengan fenomena yang sedang terjadi, kemudian penyusunan rancangan penelitian, dan juga mengadaptasi skala yang sesuai.

Pada tahap kedua, yaitu tahap pelaksanaan, pada tahap ini peneliti melakukan try out terlebih dahulu sebelum menyebar skala yang dilakukan pada tanggal 18 Februari 2019, kemudian peneliti melakukan uji validitas untuk menyaring item-item yang tidak valid sehingga mendapatkan item-item yang valid. Setelah peneliti mendapatkan item-item yang sudah valid tersebut, peneliti menyebar skala kepada subjek dengan kriteria yang sudah ditentukan, yaitu remaja yang memiliki orangtua TNI atau POLRI, usia 12 sampai 16 tahun, yang dimulai pada tanggal 11 Maret 2019 sampai dengan tanggal 18 Maret 2019.

Tahap ketiga, yaitu analisis data. Pada tahap terakhir ini peneliti entry data terlebih dahulu seblum melakukan analisa data. Proses analisa data peneliti menggunakan software perhitungan statistik SPSS (Statistical Program for Social Science) for windows versi 21.0 dengan menggunakan uji korelasi Product Moment Person.

\section{HASIL}

Berdasarkan hasil penelitian yang diperoleh dengan jumlah subjek 100 orang didapatkan hasil bahwa terdapat hubungan negatif yang signifikan antara kontrol diri dengan tingkat agresivitas pada remaja yang memiliki orangtua TNI atau POLRI, terkait dengan hal tersebut dapat diuraikan sebagai berikut.

Tabel 3. Kategori Orangtua Militer

\begin{tabular}{cccccc}
\hline Variabel & Interval & \multicolumn{3}{c}{ Orangtua Militer } & Persentase \\
& & Ayah & Ibu & Ayah dan Ibu & \\
\hline $\begin{array}{c}\text { Kontrol Diri (X) } \\
\text { Tinggi }\end{array}$ & $59-92$ & 78 & 1 & 5 & $84 \%$ \\
$\quad \begin{array}{l}\text { Rendah } \\
\text { Agresivitas (Y) }\end{array}$ & $23-58$ & 13 & 3 & - & $16 \%$ \\
Tinggi & $41-64$ & 5 & 1 & 1 & $7 \%$ \\
Rendah & $16-40$ & 86 & 3 & 4 & $93 \%$ \\
\hline
\end{tabular}


Subjek yang memiliki ayah yang bekerja di militer rata-rata memiliki kontrol diri yang tinggi dan tingkat agresivitas yang rendah, dan subjek yang memiliki ibu yang bekerja di militer memiliki kontrol diri yang rendah dan juga tingkat agresivitas yang rendah, sedangkan subjek yang kedua orang tuanya bekerja di militer rata-rata memiliki kontrol diri yang tinggi dan tingkat agresivitas yang rendah.

Tabel 4. Mean, standard deviasi, dan korelasi

\begin{tabular}{cccccc}
\hline \multicolumn{1}{c}{ Variabel } & Mean & $\begin{array}{c}\text { Standard } \\
\text { Deviasi }\end{array}$ & $\mathbf{r}$ & $\boldsymbol{r}^{2}$ & Sig. \\
\hline Kontrol Diri (X) & 32,95 & 4,487 & $-0,189$ & 0,036 & 0,030 \\
Agresivitas (Y) & 65,93 & 7,910 & & & \\
\hline
\end{tabular}

Terdapat nilai rata-rata (mean) dari variabel kontrol diri adalah 32,95 dan diperoleh nilai standar deviasi 4,487. Subjek yang memiliki kategori kontrol diri yang tinggi sebanyak 82 subjek (82\%) dengan interval kategori tinggi yaitu 59 - 92, sedangkan subjek yang memiliki kategori kontrol diri yang rendah sebanyak 18 subjek $(18 \%)$ dengan interval kategori rendah yaitu $23-58$. Nilai rata-rata (mean) dari variabel agresivitas adalah 65,93 dan diperoleh nilai standar deviasi 7,910. Subjek yang memiliki kategori agresivitas yang tinggi sebanyak 5 subjek (5\%) dengan interval kategori tinggi yaitu $41-64$, sedangkan subjek yang memiliki kategori yang rendah sebanyak 95 subjek (95\%) dengan interval kategori rendah yaitu $16-40$.

Berdasarkan hasil uji korelasi Product Moment Person yang dilakukan untuk mengetahui ada tidaknya hubungan antara kontrol diri dengan tingkat agresivitas, dapat diketahui bahwa signifikansi antara kontrol diri dan tingkat agresivitas adalah $p$ $0,030<0,05$. Maka, dapat disimpulkan bahwa terdapat hubungan negatif yang signifikan antara kontrol diri dengan tingkat agresivitas pada remaja yang memiliki orangtua TNI atau POLRI. Kemudian diketahui hasil $\mathrm{r}$ sebesar -0,189, artinya hubungan variabel kontrol diri dengan variabel agresivitas sebesar 18,9\%. Hal ini menunjukkan bahwa terdapat hubungan negatif yang signifikan dari kedua variabel, artinya semakin tinggi kontrol diri remaja tersebut maka akan semakin rendah tingkat agresivitas remaja tersebut. Selain itu, dapat diketahui juga hasil $r^{2}$ sebesar 0,036 yang artinya sumbangan variabel kontrol diri tehadap variabel agresivitas sebesar 3,6\%.

\section{DISKUSI}

Berdasarkan hasil penelitian yang dilakukan terhadap 100 subjek menunjukkan bahwa hipotesa diterima yaitu terdapat hubungan negatif yang signifikan antara kontrol diri dengan tingkat agresivitas pada remaja yang memiliki orangtua TNI atau POLRI. Artinya, semakin tinggi kontrol diri yang dimiliki individu tersebut maka semakin rendah tingkat agresivitasnya, begitupun sebaliknya ketika kontrol diri yang dimiliki individu tersebut rendah maka semakin tinggi pula tingkat agresivitasnya.

Kemampuan kontrol diri pada remaja berkaitan dengan bagaimana individu tersebut dapat mengendalikan emosi serta dorongan dari dalam dirinya sehingga individu tersebut mampu untuk membuat keputusan dan mengambil tindakan yang efektif sesuai dengan nilai-nilai moral dan harapan sosial yang ada di masyarakat. 
Kontrol diri sangat diperlukan bagi setiap individu karena dalam kehidupannya seseorang tidak bisa hidup sendiri dan membutuhkan bantuan orang lain, agar seseorang tersebut tidak melanggar hak dan membahayakan orang lain, maka seorang individu harus dapat mengontrol perilaku-perilaku negatif yang dimilikinya (Calhoun dan Acocella, 1995). Tingkatan kontrol diri yang dimiliki setiap individu berbeda-beda, hal tersebut dipengaruhi oleh dua faktor, yaitu faktor internal dan faktor eksternal. Faktor internal meliputi faktor usia dan kematangan, sedangkan faktor eksternalnya adalah pengaruh lingkungan. Dimana semakin bertambah usia seseorang, maka kontrol diri yang dimiliki seseorang tersebut akan semakin baik, seseorang yang telah siap secara psikologis juga akan berpengaruh pada diri seorang individu tersebut agar dapat mengontrol setiap perilaku yang dilakukannya, karena pada dasarnya seseorang telah mampu mempertimbangkan mana hal yang baik dan hal yang buruk bagi dirinya (Hurlock, 2004).

Penelitian ini sesuai dengan hasil penelitian yang dilakukan oleh DeWall, Finkel, dan Denson (2011), yaitu hasil penelitian menyatakan bahwa kegagalan kontrol diri dapat memberikan kontribusi untuk tindakan yang paling agresif yang menyertakan kekerasan. Ketika perilaku agresif itu muncul, maka kontrol diri dapat membantu individu tersebut untuk merespon sesuai dengan standar pribadi atau sosial yang dapat menahan atau mengurangi munculnya perilaku agresif tersebut.

Sejumlah 82 subjek menunjukkan hasil dalam kategori kontrol diri yang tinggi. Artinya, sejumlah $82 \%$ subjek memiliki kemampuan dalam hal mengendalikan sesuatu yang berhubungan dengan dirinya, dapat berupa emosi atau perilaku, dan juga dapat mengendalikan perilaku negatif seseorang yang muncul dengan cara mempertimbangkannya terlebih dahulu. Sedangkan sejumlah 18 subjek menunjukkan hasil dalam kategori yang rendah. Artinya, sejumlah 18\% subjek kurang memiliki kemampuan dalam hal mengendalikan sesuatu berhubungan dengan dirinya sendiri, yang berupa emosi atau perilaku, dan juga dapat mengendalikan perilaku negatif seseorang yang muncul dengan cara mempertimbangkannya terlebih dahulu.

Sejumlah 5 subjek menunjukkan hasil dalam kategori tingkat agresivitas yang tinggi. Artinya, sejumlah 5\% subjek masih berpotensi untuk berperilaku agresif yang dapat membahayakan orang lain, dimana pelakunya tersebut melakukan perilaku agresif dengan unsur kesengajaan untuk menyakiti lawannya. Sedangkan sejumlah 95 subjek menunjukkan hasil dalam kategori tingkat agresivitas yang rendah. Artinya, sejumlah 95\% subjek tidak berperilaku agresif yang dapat membahayakan orang lain.

Penelitian ini juga menunjukkan bahwa remaja dalam kategori kontrol diri yang tinggi sebesar $82 \%$, dan remaja dengan kategori tingkat agresivitas yang tinggi sebesar $5 \%$. Artinya, sebesar $82 \%$ adalah remaja yang memiliki kontrol diri yang tinggi tingkat agresivitasnya juga akan semakin rendah. Hal tersebut dapat menjelaskan bahwa kontrol diri merupakan salah satu faktor yang dapat menurunkan atau meminimalisir tingkat agresivitas seseorang.

Dalam penelitian ini juga mengatakan bahwa remaja yang memiliki ayah yang bekerja di militer rata-rata memiliki kontrol diri yang tinggi dan tingkat agresivitas yang rendah, dapat dilihat dari hasil penelitian ini ayah juga memiliki keterlibatan dalam memberikan pengasuhan terhadap remaja. Hal tersebut sesuai dengan penelitian yang dilakukan oleh Susanto (2013) yang mengatakan bahwa keterlibatan 
ayah dalam kehidupan remaja akan berhubungan dengan teman sebaya dan prestasi di sekolah, serta membantu remaja dalam mengembangkan pengendalian dan penyesuaian diri dalam lingkungannya. Subjek yang memiliki ibu yang bekerja di militer memiliki kontrol diri yang rendah dan juga tingkat agresivitas yang rendah, maka dari itu peran ibu sangat dibutuhkan dalam proses pengasuhan. Sedangkan subjek yang kedua orangtuanya bekerja di militer rata-rata memiliki kontrol diri yang tinggi dan tingkat agresivitas yang rendah, dari hal tersebut maka peran kedua orangtua sangat penting bagi pertumbuhan remaja. Sesuai dengan hal tersebut orangtua yang bekerja sebagai TNI maupun POLRI memiliki cara tersendiri untuk memberikan pola pengasuhan terhadap anaknya, sehingga dengan cara pola pengasuhan yang berbeda-beda akan sangat berpengaruh terhadap kontrol diri yang ditunjukkan melalui sikap dan perilaku remaja tersebut. Ketika muncul perilaku agresif dalam diri seseorang, remaja dengan kontrol diri yang baik akan dapat mengontrol atau menahan munculnya perilaku tersebut.

Pada proses penelitian ini pastinya penelitian ini memiliki kelemahan. Kelemahan tersebut yaitu penelitian ini menggunakan metode korelasional atau hubungan, dimana metode korelasional atau hubungan ini tidak menjelaskan sebabakibat. Pada penelitian ini juga tidak mendapatkan subjek secara merata dalam kategori jenis kelamin, sehingga tidak dapat dipertimbangkan. Sedangkan keunggulan dari penelitian ini adalah didapatkan beberapa temuan yang dapat diteliti oleh peneliti selanjutnya, yaitu bagaimana kontrol diri dan tingkat agresivitasnya ketika remaja berada di dalam keluarga yang ayah dan ibunya bekerja di militer, dan bagaimana kontrol diri dan tingkat agresivitasnya ketika remaja berada di dalam keluarga yang salah satu orangtuanya (ayah atau ibu) yang bekerja di militer. Kemudian penelitian ini juga dapat menjadi bahan pertimbangan atau gambaran untuk memberikan intervensi peningkatan kontrol diri pada remaja sehingga remaja tersebut dapat mengurangi tingkat agresivitasnya.

\section{SIMPULAN DAN IMPLIKASI}

Berdasarkan hasil analisa dalam penelitian ini menunjukkan bahwa hipotesa penelitian ini diterima, yang artinya terdapat hubungan negatif yang signifikan antara kontrol diri dengan tingkat agresivitas pada remaja yang memiliki orang tua TNI atau POLRI. Semakin tinggi kontrol diri yang dimiliki seseorang maka akan semakin rendah tingkat agresivitasnya, sebaliknya semakin rendah kontrol diri seseorang maka akan semakin tinggi tingkat agresivitasnya. Dari penelitian ini juga di dapat disimpulkan mengenai remaja yang memiliki ayah yang bekerja di militer rata-rata memiliki kontrol diri yang tinggi dan tingkat agresivitas yang rendah, dan subjek yang memiliki ibu yang bekerja di militer memiliki kontrol diri yang rendah dan juga tingkat agresivitas yang rendah, sedangkan subjek yang kedua orang tuanya bekerja di militer rata-rata memiliki kontrol diri yang tinggi dan tingkat agresivitas yang rendah.

Implikasi dari penelitian ini adalah tingkat agresivitas remaja dapat diminimalisir. Salah satu caranya yaitu dengan meningkatkan kontrol diri dalam diri remaja tersebut, sehingga para remaja bisa memperbaiki dan menjadi pribadi yang lebih baik lagi. Rekomendasi untuk peneliti selanjutnya yaitu dapat menjadikan kekurangan dari penelitian ini untuk menjadikan tolak ukur untuk melakukan 
penelitian selanjutnya yang lebih baik lagi, serta dapat mengembangkan penelitian ini dengan subjek yang berbeda.

\section{REFERENSI}

Aroma, I. S., \& Suminar, D. R. (2012). Hubungan antara tingkat kontrol diri dengan kecenderungan perilaku kenakalan remaja. Journal Psikologi Pendidikan dan Perkembangan Vol. 1(2), 5-6.

Antasari. (2006). Menyikapi perilaku agresif anak. Yogyakarta: Kanisius.

Averill, J. R. (1983). Studies on anger and aggression: Implications for theories of emotion. American Psychologist, 38, 1145-1160.

Baron, R.A, \& B. D. (1994). Social psychology: Understanding human interaction. Boston: allyn \& Bacon, Inc.

Baumeister, R. F., Vohs, K. D., dan Tice, D. M. 2007. The Strength Model of Self-Control. Association for Psychological Science Vol. 16(6), 351-355.

Benjamin, A. J. (2015). Aggression. Encyclopedia of mental health: Second Edition, 1, 33-39. https://doi.org/10.1016/B978-0-12-397045-9.00198-1

Brookings, J. B., DeRoo, H., \& Grimone, J. (2008). Predicting driving anger from trait aggression and self-control. Psychological Reports, 103, 622-624.

Calhoun, J.F \& Acocella, J.R. (1995). Psikologi tentang penyesuaian dan hubungan kemanusiaan. Semarang: IKIP Semarang Press.

Chaplin, J. P. (2001). Kamus lengkap psikologi. Jakarta: Raja Grafindo Perkasa.

DeWall, C. N., Finkel, E.J. \& Denson, T. F.(2011). Self-control inhibits aggression. Social and personality psychology compass. 5(7), 458-472.

Emilianur, E., \& Amri, A. (2017). POLA PENGASUHAN ANAK PADA KELUARGA MILITER (Suatu Penelitian di Asmil Kompi Panser 11.1 Lhoknga, Yonkav 11/Serbu Aceh Besar). Jurnal Ilmiah Mahasiswa Fakultas Ilmu Sosial \& Ilmu Politik, 2(4).

Ghufron. (2010). Teori-teori perkembangan. Bandung: Refika Aditama.

Goldfried, M. R., \& Merbaum, M (1973). Behavior change through self-control. New York: Holt, Rinehart \& Winston.

Havighurst, R.J., Neugarten, B.L. \& Tobin, S. S. (1964). Disengagement personality and life satisfaction in the later years. Copenhagen: Munksgaard.

Hudaniah, T. D. \&. (2012). Psikologi sosial. Malang: UMM Press.

Hurlock. (2004). Psikologi perkembangan suatu pendekatan sepanjang rentang kehidupan. Jakarta: Erlangga.

Johnson, R.J., \& Meddinus, G.R. (1976). Child and Adolescence Psychology. New York: John Wiley and Sons, Inc.

Krahe, B. (2001). The social psychology of aggression. East Sussex: Psychology Press

Koeswara, E. (1988). Agresi manusia. Bandung: PT Eresco.

Monks, F.J., Knoers, A.M.P., Haditono, S. R. (2006). Psikologi perkembangan: Pengantar dalam berbagai bagiannya. Yogyakarta: Gadjah Mada University Press.

Murray, R. K., Granner, D. K., \& Rodwell, V. W (2009) . Biokimia harper (27 ed.). Jakarta: Buku Kedokteran EGC;

Myers, David G. (2012). Psikologi sosial jilid 2. Jakarta: Salemba Humanika.

Praditya, L. D., Wimbarti, S., \& Helmi, A., F. (1999). Pengaruh tayangan adegan kekerasan yang nyata terhadap agresivitas. Jurnal psikologi, Vol 1(1), 1-12.

Purwanto. (2015). Metodologi penelitian kuantitatif untuk psikologi dan pendidikan. (B. Santoso, Ed.). Yogyakarta: Pustaka Belajar.

Rosmha Widiyani. (2014). Kasus Ade Sara, Dampak Salah Asuh Orangtua?. Kompas.com. https://lifestyle.kompas.com/read/2014/03/10/1455563/Kasus.Ade.Sara.Dampak.Salah.Asu 
Cognicia

http://ejournal.umm.ac.id/index.php/cognicia

h.Orangtua.

Schneider, Kerri M. (2005). Aggression and Cardivascular Response in Children. Journal Of Pediatric Psychology, Vol. 27(7), 565-573.

Soekanto, S. (1988). Sosiologi penyimpangan. Jakarta: Radjawali.

Susanto, D. (2013). Keterlibatan ayah dalam pengasuhan, kemampuan coping dan resiliensi remaja. Jurnal Sains Dan Praktik Psikologi Magister Psikologi UMM, 1 (2), 101 - 113.

Tangney, J.P., Baumeister R. F., \& Boone, A. L. (2004). High self-control predicts good adjusment, less psychology, better grades, and interpersonal succes. Journal Of Personality 72:2 Blackwell Publishing.

Ubaidillah, M. A. (2017). Hubungan kontrol diri dengan agresivitas santri baru pondok pesantren ilmu Al-Qur'an Singosari Malang, (12410143). 